TABLE II-Effect of duration of oral contraceptive use on relation between thromboembolism and smoking habits

\begin{tabular}{|c|c|c|c|c|c|c|}
\hline \multirow{2}{*}{$\begin{array}{l}\text { Duration of oral } \\
\text { contraceptive use } \\
\text { (years) }\end{array}$} & \multicolumn{2}{|c|}{ Patients with thromboembolism } & \multirow{2}{*}{ Total } & \multicolumn{2}{|c|}{ Controls } & \multirow{2}{*}{ Total* } \\
\hline & Smokers $\left({ }^{\circ}\right)$ & Non-smokers (" $\left.{ }_{0}\right)$ & & Smokers (" $\left.{ }^{\prime \prime}\right)$ & Non-smokers $\left({ }^{\prime \prime}{ }_{11}\right)$ & \\
\hline $\begin{array}{l}<1 \\
1-5 \\
6\end{array}$ & $\begin{array}{r}11(46) \\
16(59) \\
7(78)\end{array}$ & $\begin{array}{r}13(54) \\
11(41) \\
2(22)\end{array}$ & $\begin{array}{r}24 \\
37 \\
9\end{array}$ & $\begin{array}{l}49(54) \\
42(66) \\
11(61)\end{array}$ & $\begin{aligned} 42(46) \\
21(33) \\
7(39)\end{aligned}$ & $\begin{array}{l}91 \\
63 \\
18\end{array}$ \\
\hline
\end{tabular}

${ }^{*}$ Eight controls were excluded as duration of oral contraceptive use was not recorded.

reported in the remaining $38(21 \%)$. The mean age of the 60 patients was 29 ( \pm standard error of mean 1.0 ) years, and of the 180 controls was $26( \pm 0 \cdot 5)$ years.

\section{Results}

Twenty-six $(43 \%)$ of the oral contraceptive users with uncomplicated thromboembolism were non-smokers compared with $72(40 \%)$ of the controls (table I). Likewise, five $(8 \%$ ) of the patients and $22(12 \%)$ of the controls smoked more than 20 cigarettes daily. Thus there was no evidence of a relation between uncomplicated thromboembolism and smoking habits.

A review of the data in the light of information on duration of oral contraceptive use again failed to show an association between thromboembolism and smoking habits (table II). Furthermore, stratification of the patients according to where they had been admitted to hospital showed that this was not a confounding variable.

\section{Discussion}

This study provides strong evidence against a major effect of smoking on the risk of thromboembolism in a group of otherwise healthy women using oral contraceptives. The patients taking part in the study were all interviewed as part of a large, continuous drug surveillance programme. The details of their smoking habits and history of oral contraceptive use were taken as part of an extensive interview, and were recorded before the hypotheses at issue had been proposed. Therefore, it is highly unlikely that there was any bias when histories were taken, either for patients or controls.

Since there are considerable differences in the smoking habits of patients in different age groups, we took this factor into account by a matching procedure. The latter was also used to take into account any differences which could have arisen between the two sources of information which comprised the study population.

It is extremely unlikely that there were differences relating to smoking habits in the criteria used to make the diagnosis of thromboembolism or deep venous thrombosis within this set of oral contraceptive users. Moreover, since patients admitted with diseases related to smoking were excluded from the study, the smoking habits of the controls probably reflected the habits of communities from which they were drawn.

Our results suggest that the differences in the activities of the coagulation and fibrinolytic systems in smokers and nonsmokers reported by Meade and his colleagues ${ }^{6}$ are not major factors in the aetiology of uncomplicated venous thrombosis in women using oral contraceptives. These differences may be important, however, in explaining the proposed synergistic effect of smoking and oral contraceptive use on the risk of myocardial infarction in young women, which was recently reported by Mann et al in Oxford. ${ }^{\circ}$

\section{References}

1 Vessey, M P, and Doll, R, British Medical fournal, 1968, 2, 199.

2 Vessey, M P, and Doll, R, British Medical fournal, 1969, 2, 651.

${ }^{3}$ Sartwell, P E, et al, American fournal of Epidemiology, 1969, 90, 365.

${ }^{4}$ Boston Collaborative Drug Surveillance Program, Lancet, 1973, 1, 1399.

${ }^{5}$ Dugdale, M, and Masi, A T, fournal of Chronic Diseases, 1971, 23, 775.

${ }^{6}$ Meade, T W, et al, British fournal of Haematology, 1976, 34, 353.

' Jick, H, et al, fournal of the American Medical Association, 1970, 213, 1455.

" Mann, J I, et al, British Medical fournal, 1975, 2, 241.
Liverpool Maternity Hospital, Liverpool L7 7BN

A R L WEEKES, FRCSED, MRCOG, senior registrar

V E CHERIDJIAN, MB, MRCOG, registrar

D K MWANJE, MB, FFARCs, senior registrar the proportion of breech extractions when either the first or second twin presented by the breech; the incidence of low Apgar scores; and the perinatal mortality were not significantly different in the two groups.

These findings suggest that lumbar epidural analgesia is safe for providing pain relief in labour for patients with a twin pregnancy. Moreover, an epidural block is preferable to conventional analgesia in these cases as it allows prompt intervention to effect delivery of the second twin.

\section{Introduction}

In singleton pregnancies the administration of epidural analgesia in labour is safe for both mother and fetus.' Its use in labour in patients with a twin pregnancy, however, is controversial. It 
TABLE I-Details of the mothers and gestational age and mode of presentation of first twin

\begin{tabular}{|c|c|c|c|c|c|c|c|c|c|c|}
\hline \multirow{3}{*}{ Group } & \multicolumn{6}{|c|}{ Mother } & \multicolumn{4}{|c|}{ Fetus } \\
\hline & \multirow{2}{*}{$\overline{\text { Mean }(: S D)}$} & \multirow{2}{*}{$\mid \begin{array}{c}\text { Mean }(: \mathrm{SD}) \\
\text { height }(\mathrm{cm})\end{array}$} & \multirow{2}{*}{$\begin{array}{c}\text { No of } \\
\text { primiparae }\end{array}$} & \multirow{2}{*}{$\begin{array}{c}\text { No of } \\
\text { multiparae }\end{array}$} & \multirow{2}{*}{$\begin{array}{l}\text { No who were } \\
\text { hypertensive }\end{array}$} & \multirow{2}{*}{$\begin{array}{l}\text { No with } \\
\text { induced } \\
\text { labour }\end{array}$} & \multicolumn{2}{|c|}{ Gestational age } & \multicolumn{2}{|c|}{ Presentation of 1 st twin } \\
\hline & & & & & & & $<36$ weeks & 36 weeks & Head & Breech \\
\hline $\begin{array}{l}\text { Epidural }(n=50) \\
\text { Non-epidural }(n=92)\end{array}$ & $\begin{array}{l}26.98: 5 \cdot 32 \\
27 \cdot 35: 4.98\end{array}$ & $\begin{array}{r}160 \cdot 87: 5 \cdot 4 \\
160 \cdot 9: 6 \cdot 3\end{array}$ & $\begin{array}{l}23 \\
31\end{array}$ & $\begin{array}{l}27 \\
61\end{array}$ & $\begin{array}{l}12 \\
38\end{array}$ & $\begin{array}{l}12 \\
20\end{array}$ & $\begin{array}{r}5 \\
20\end{array}$ & $\begin{array}{l}45 \\
72\end{array}$ & $\begin{array}{l}40 \\
78\end{array}$ & $\begin{array}{l}10 \\
14\end{array}$ \\
\hline Significance & $\begin{array}{l}t=0.41 \\
\mathrm{P}=0.69\end{array}$ & $\begin{array}{l}t=0.07 \\
\mathrm{P}=0.94\end{array}$ & \multicolumn{2}{|c|}{$\%^{2}=1.59 ; 1 \mathrm{DF} ;$} & $\begin{array}{c}X^{2}=0.32 \\
1 \mathrm{DF} ; \mathrm{P}=0.57\end{array}$ & $\begin{array}{c}Y^{2}=0.012 \\
1 \mathrm{DF} ; \mathrm{P}=0.92\end{array}$ & \multicolumn{2}{|c|}{$\begin{aligned} Y^{2}= & 2.32 ; 1 \mathrm{DF} ; \\
\mathrm{P}=0.13 & \end{aligned}$} & \multicolumn{2}{|c|}{$\begin{aligned} \varkappa^{2}=0.242 ; 1 \mathrm{DF} \\
P=0.62\end{aligned}$} \\
\hline
\end{tabular}

has been suggested that the use of epidural analgesia in labour in patients with a multiple pregnancy is associated with an increased perinatal mortality, ${ }^{2} 3$ but a more recent study by J Selwyn Crawford ${ }^{+}$cautiously recommended its use in labour in twin pregnancy.

We were therefore prompted to compare the course of labour and the fetal outcome in twin pregnancies managed with and without continuous lumbar epidural analgesia.

\section{Patients and methods}

We studied 158 consecutive women who were delivered of twins at the Liverpool Maternity Hospital. We excluded two women who had twin abortions, six women who had elective caesarean sections, and three patients with a macerated stillbirth of one or both twins. Patients who required emergency caesarean section were also excluded. One patient in the epidural group and four in the parenteral group were also excluded because emergency caesarean section had to be performed for fetal distress. The final analysis covered 50 patients who had epidural analgesia and 92 patients who had parenteral analgesia.

Bupivacaine $0.5 \%$ with adrenaline $1 / 400000$ was given to the patients who had epidural analgesia. An initial test dose of $2 \mathrm{ml}$ was given, and incremental doses of $4 \mathrm{ml}$ were then given as required; $6 \mathrm{ml}$ was administered in the sitting position when the cervix was fully dilated and the presenting part visible. Parenteral analgesia during labour was provided by pethidine $150 \mathrm{mg}$ and promethazine hydrochloride $25 \mathrm{mg}$ as required, supplemented by nitrous oxide and oxygen (Entonox). Ten patients in this group required a general anaesthetic to expedite the delivery of the second twin.

The $\%$ test with Yates's correction and Student's $t$ tests were used in the statistical evaluation.

\section{Results}

The two groups were comparable in maternal age, height, parity, the incidence of hypertension in pregnancy, and incidence of induced labour (table I). The paediatric assessment of gestational age and the mode of presentation of the first twin were also similar in the two groups (table I).

Duration of labour-The duration of the first stage of labour, from full dilatation to delivery of the first twin, and the time interval between the delivery of the first and second twins were similar (table II).

Mode of delivery-The mode of delivery in the two groups is shown in table III. The proportion of vertex deliveries that required forceps assistance because of poor maternal expulsive effort was similar in the two groups. Twelve of the 40 first twins in the epidural group and 15 of the 78 in the non-epidural group needed forceps assistance for this reason $\left(\chi^{2}=1 \cdot 18 ; 1 \mathrm{DF} ; \mathrm{P}=0 \cdot 28\right)$, while nine of the 23 second

TABLE II-Duration of the various stages of labour. Values are means $\pm S D$

\begin{tabular}{|c|c|c|c|}
\hline Group & $\begin{array}{l}\text { First stage } \\
\text { (h) }\end{array}$ & $\begin{array}{l}\text { Full dilatation to } \\
\text { delivery of } 1 \text { st twin } \\
\text { (min) }\end{array}$ & $\begin{array}{l}\text { Delivery of } 1 \text { st twin } \\
\text { to delivery of } 2 \mathrm{nd} \\
\text { (min) }\end{array}$ \\
\hline $\begin{array}{l}\text { Epidural } \\
\text { Non-epidural }\end{array}$ & $\begin{array}{l}6.69: 4.99 \\
6.80: 5.70\end{array}$ & $\begin{array}{l}26 \cdot 68: 23 \cdot 06 \\
21 \cdot 16: 20 \cdot 33\end{array}$ & $\begin{array}{l:l}12 \cdot 16 & 10.30 \\
11.06 & 6.94\end{array}$ \\
\hline Significance & $\begin{array}{c}t=0.12 ; 138 \mathrm{DF} \\
\mathbf{P}=0.90\end{array}$ & $t=1 \cdot 46 ; 137 \mathrm{DF}$ & $\begin{array}{c}t=0.73 ; 131 \mathrm{DF} \\
\mathrm{P}=0.46\end{array}$ \\
\hline
\end{tabular}

TABLE III-Mode of delivery of twins in the two groups

\begin{tabular}{|c|c|c|c|c|}
\hline & \multicolumn{2}{|c|}{ 1st twin } & \multicolumn{2}{|c|}{ 2nd twin } \\
\hline & Epidural & Non-epidural & Epidural & Non-epidural \\
\hline $\begin{array}{l}\text { Spontaneous vertex } \\
\text { Forceps } \\
\text { Assisted breech } \\
\text { Breech extraction } \\
\text { Internal version and } \\
\text { breech extraction }\end{array}$ & $\begin{array}{l}20 \\
20(12)^{*} \\
9 \\
1 \\
0\end{array}$ & $\begin{array}{l}45 \\
33(15)^{*} \\
13 \\
1 \\
0\end{array}$ & $\begin{array}{r}14 \\
9 \\
14 \\
12 \\
1\end{array}$ & $\begin{array}{l}18 \\
32(14)^{*} \\
24 \\
8 \\
10\end{array}$ \\
\hline Total & 50 & 92 & 50 & 92 \\
\hline
\end{tabular}

*Figures in parentheses represent the number of forceps deliveries performed for poor maternal expulsive effort.

twins in the epidural group and 14 of the 50 in the non-epidural group did so $\left(\%^{2}=0.46 ; 1 \mathrm{DF} ; \mathrm{P}=0.51\right)$. The proportion of patients in each group who required breech extraction to effect delivery of the second twin was also similar $\left(y^{2}=1.98 ; 1 \mathrm{DF} ; \mathrm{P}=0 \cdot 16\right)$.

Apgar score-A similar proportion of babies in the two groups had an Apgar score of less than 7 . When the second twin presented by the breech a higher proportion of those in the non-epidural group had an Apgar score of less than 7 . But this difference did not reach the $5 \%$ level of significance. Moreover, 10 of these patients had internal podalic version and breech extraction (table IV).

Perinatal mortality-There were 10 perinatal deaths $(3.5 \%)$, two of which were in the epidural group. Both of the babies in the epidural group died from the respiratory distress syndrome, as did six infants in the non-epidural group. One baby died after a tentorial tear and another as a result of severe Rhesus incompatability.

\section{Discussion}

We found no evidence to suggest that the administration of a lumbar epidural block during labour in twin pregnancy

TABLE IV-Apgar score at one minute in all infants in the two groups, in vertex deliveries, and in breech deliveries

\begin{tabular}{|c|c|c|c|c|}
\hline \multirow{2}{*}{ Apgar score } & \multicolumn{2}{|c|}{$1 \mathrm{st}$ twin } & \multicolumn{2}{|c|}{ 2nd twin } \\
\hline & Epidural & Non-epidural & Epidural & Non-epidural \\
\hline \multicolumn{5}{|c|}{ All deliveries } \\
\hline $\begin{array}{r}<7 \\
7\end{array}$ & $\begin{array}{l}15 \\
35\end{array}$ & $\begin{array}{l}23 \\
69\end{array}$ & $\begin{array}{l}17 \\
33\end{array}$ & $\begin{array}{l}45 \\
47\end{array}$ \\
\hline Total & 50 & 92 & 50 & 92 \\
\hline Significance & \multicolumn{2}{|c|}{$\%^{2}=0.20 ; 1 \mathrm{DF} ; \mathrm{P}=0.66$} & \multicolumn{2}{|c|}{$\mathrm{X}^{2}=2.35 ; 1 \mathrm{DF} ; \mathrm{P}=0.13$} \\
\hline \multicolumn{5}{|c|}{ Vertex deliveries } \\
\hline $\begin{array}{r}<7 \\
7\end{array}$ & $\begin{array}{r}9 \\
31\end{array}$ & $\begin{array}{l}13 \\
65\end{array}$ & $\begin{array}{r}4 \\
19 \\
\end{array}$ & $\begin{array}{l}19 \\
31 \\
\end{array}$ \\
\hline Total & 40 & 78 & 23 & 50 \\
\hline Significance & \multicolumn{2}{|c|}{$\dddot{Y}^{2}=0.27 ; 1 \mathrm{DF} ; \mathrm{P}=0.60$} & \multicolumn{2}{|c|}{$\not^{2}=2.22 ; 1 \mathrm{DF} ; \mathrm{P}=0.14$} \\
\hline \multicolumn{5}{|c|}{ Breech deliveries } \\
\hline $\begin{array}{r}<7 \\
\quad 7\end{array}$ & $\begin{array}{l}6 \\
4 \\
\end{array}$ & $\begin{array}{r}10 \\
4 \\
\end{array}$ & $\begin{array}{l}13 \\
14 \\
\end{array}$ & $\begin{array}{l}26 \\
16 \\
\end{array}$ \\
\hline Total & 10 & 14 & 27 & 42 \\
\hline Significance & \multicolumn{2}{|c|}{$\varkappa^{2}=0.02 ; 1 \mathrm{DF} ; \mathrm{P}=0.88$} & \multicolumn{2}{|c|}{$\varkappa^{2}=0.77 ; 1 \mathrm{DF} ; \mathrm{P}=0.38$} \\
\hline
\end{tabular}


adversely affects neonatal outcome as assessed by the oneminute Apgar score and perinatal mortality. Five- and 10minute Apgar scores were not evaluated as too few infants in either group had Apgar scores under 7 at five or 10 minutes to allow meaningful comparison.

No differences were found in either the interval between full dilatation and delivery of the first twin or the forceps rate for poor maternal effort in the two groups. This was probably related to our practice of waiting for the presenting part to become visible before encouraging the patient to push.

It has already been shown that the use of an epidural block in labour in singleton breech presentations does not increase the incidence of breech extraction. ${ }^{5}{ }^{6}$ Our study has shown that neither does it increase the incidence of breech extractions when either twin presents by the breech.

We conclude therefore that epidural block is safe in labour in twin pregnancy. It affords better pain relief and allows prompt intervention should intrauterine manipulations be necessary to effect delivery of the second twin.

We thank the consultant obstetricians who allowed us to study patients under their care and $\mathrm{Mr} \mathrm{C} \mathrm{R} \mathrm{West,} \mathrm{who} \mathrm{kindly} \mathrm{helped} \mathrm{with}$ the statistical analysis.

\section{References}

${ }^{1}$ Crawford, J S, British fournal of Anaesthesia, 1972, 44, 66.

${ }^{2}$ Little, W A, and Freidman, E A, Anesthesiology, 1958, 19, 515.

${ }^{3}$ Guttmacher, A F, New York State Fournal of Medicine, 1957, 57, 2538.

4 Crawford, J S, British fournal of Obstetrics and Gynaecology, 1975, 82,929.

${ }^{5}$ Darby, S, et al, British fournal of Obstetrics and Gynaecology, 1976, 83, 35.

6 Crawford, J S, Fournal of Obstetrics and Gynaecology of the British Commonwealth, 1974, 81, 867.

\title{
Respiratory arrest in familial hemiplegic migraine: a clinical and neuropathological study
}

\author{
P NELIGAN, D G F HARRIMAN, JOHN PEARCE
}

British Medical fournal, 1977, 2, 732-734

\begin{abstract}
Summary
We describe a fatal case of familial hemiplegic migraine. A transient respiratory arrest in this patient led to a persistent "vegetative state," culminating in death four months later. Neuropathological findings included deep microinfarcts in the basal ganglia and a remarkable sparing of brain-stem nuclei associated with the function of respiration.
\end{abstract}

\section{Introduction}

Known complications of migraine include persisting hemiparesis, facial weakness, ophthalmoplegic and visual field defects. Deaths have been attributed to migraine, ${ }^{2}{ }^{3}$ but terminal anoxia in some cases makes pathological interpretation difficult. We describe a patient who suffered respiratory arrest during an attack of hemiplegic migraine, which led to a "persistent vegetative state." By familial hemiplegic migraine, we refer to the condition defined by the World Federation of Neurologists Research Group as "a rare condition, which may exhibit a dominant inheritance, characterised by episodic migrainous attacks associated with hemiplegia outlasting the headache."1

\section{Case report}

A 41-year-old, right-handed housewife presented at Hull Royal Infirmary as an emergency admission in October 1976. She was a

Department of Neurology and Migraine Clinic, Hull Royal Infirmary, Hull HU3 2JZ

P NELIGAN, MB, MRCP, registrar (now general practitioner, Bishop Auckland, Co Durham)

JOHN PEARCE, MD, FRCP, consultant neurologist

Neuropathology Unit, General Infirmary, Leeds LS1 3EX

D G F HARRIMAN, MD, FRCP, FRCPATH, senior lecturer and consultant neuropathologist member (IIc) of a family with hemiplegic migraine (fig 1). All the affected members shown in the pedigree suffered from hemiplegic migraine, with paresis lasting from two hours up to seven days in various attacks we have observed. In 1972 she had described attacks of severe right or left frontal headache, accompanied after five minutes by numbness and weakness of limbs of either side, which had occurred since the age of 9 . The face, arm, and leg were affected, with variable dysphasia and sickness, but no visual disturbance. Attacks lasted up to one hour. She had had no such attack since 1962.

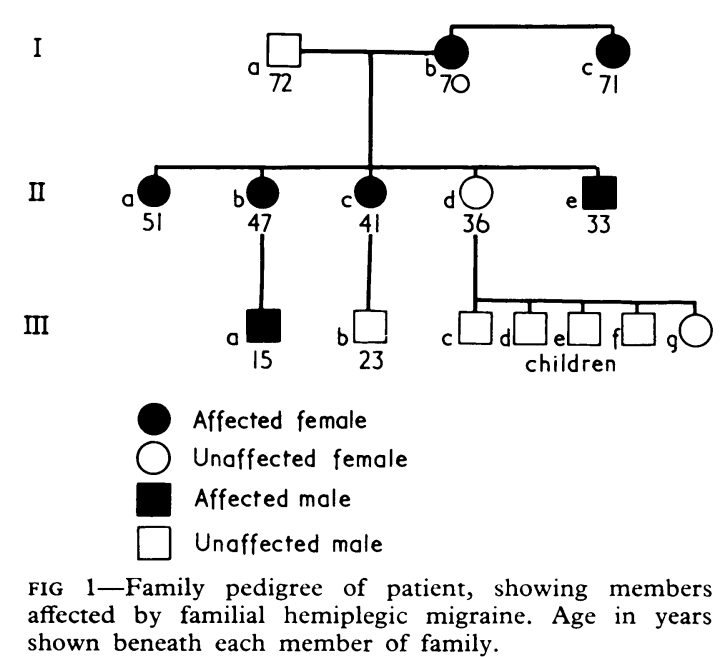

Thirty-six hours before admission she awoke with severe right temporal headache, and some minutes later was unable to use her left arm. She had not taken oral contraceptives. On admission she was drowsy, but would talk coherently, and was orientated when roused. She was feverish $\left(38.5^{\circ} \mathrm{C}\right)$, irritable, and photophobic; her neck was stiff. She had a moderate left hemiparesis, and the fundi were normal. In view of the previous episodes and family history we diagnosed hemiplegic migraine.

The next day she developed alternating left- and right-sided epileptic attacks, on occasions becoming generalised, lasting two minutes, and recurring frequently. She remained unconscious 